\title{
Histopathology from liver of tuvira (Gymnotus spp.) parasitized by larvae of nematodes
}

\author{
Histopatologia de fígado de tuvira parasitado por larvas de nematoides
}

\author{
Arlene Sobrinho Ventura ${ }^{\mathrm{I}}$ Márcia Mayumi Ishikawa ${ }^{\mathrm{II}}$ Andrea Maria de Araújo Gabriel ${ }^{\mathrm{II}}$ \\ Helcy Lylian Nogueira Silbiger ${ }^{\mathrm{IV}}$ Fabiana Cavichiolo $^{\mathrm{III}}$ Ricardo Massato Takemotov $^{\mathrm{V}}$
}

\section{ABSTRACT}

The aim of this study was to evaluate the histological changes in the liver of thirty-five Gymnotus spp. parasitized by endohelminths collected between April 2012 to October 2013 in commercial bait fish farming of Pantanal basin. Histological cuts of $7 \mu \mathrm{m}$ were stained with hematoxylin-eosin for parasites research and liver changes and have also been submitted to the Perls histochemical method for evaluation of hemosiderosis $(\mathrm{Fe}+++$ ) based on the incidence degree and severity of change (Grade I, II and III) and tests for the presence of central melanomacrophages. Parasites identified were: Brevimulticaecum sp. with a prevalence of 22,9\%, Eustrongylides sp 17,1\%, Contracaecum type I 68,7\%, Contracaecum type II 5,7\%, Contracaecum type III 5,7\% and larvae of Anisakidae 11,4\%. Histological analysis showed intense disorganization of hepatic parenchyma with degenerate hepatocytes due to high parasitic infection, changes that can be deleterious and compromise the organism functioning, being harmful to the health of evaluated animals. Also evidencing normal tissue interleaved with different stages of $\mathrm{Fe}+++$ deposit in grades II and III, injuring or destroing the cell. Histopathological changes in the tuvira's liver suggested a chronic response and the development of a balance relation between tuvira and parasitism by endohelminth identified in this study. There are also a testimony to the health condition of commercial bait fish farming on current ecosystem conditions.

Key words: hepatic histopathology, parasitology, commercial bait fish farming, Anisakidae, Gymnotus spp.

\section{RESUMO}

O objetivo deste estudo foi avaliar as alterações histológicas do figado de trinta e cinco Gymnotus spp. parasitados por endohelmintos, coletados entre abril de 2012 a outubro de 2013, em isqueiros da bacia do Pantanal. Cortes histológicos de 7 um foram corados com hematoxilina-eosina para pesquisa de parasitos e de alterações hepáticas; também foram submetidos ao método histoquímico de Perls para avaliação de hemossiderose $\left(\mathrm{Fe}^{+++}\right)$com base no grau de incidência $e$ severidade da alteração (Grau I, II e III) e pesquisa da presença de centro de melanomacrófagos. Os parasitos identificados foram: Brevimulticaecum sp., com prevalência de 22,9\%, Eustrongylides sp. 17,1\%, Contracaecum tipo I 68,7\%, Contracaecum tipo II 5,7\%, Contracaecum tipo III 5,7\% e larvas de Anisakidae 11,4\%. A análise histológica revelou intensa desorganização do parênquima hepático, com hepatócitos degenerados devido à alta infecção parasitária. Essas alterações podem ser deletérias e comprometer o funcionamento do organismo, sendo prejudicial à saúde dos animais avaliados; também evidenciou tecido normal intercalado com estágios diferenciados de depósito de $\mathrm{Fe}^{+++}$nos Graus II e III, podendo lesionar ou destruir a célula. As alterações histopatológicas do figado das tuviras sugerem uma resposta crônica e o desenvolvimento de uma relação de equilíbrio entre a tuvira e o parasitismo pelos endohelmintos identificados neste estudo. Elas também são um testemunho da condição de saúde dos peixes dos isqueiros nas condições atuais do ecossistema.

Palavras-chave: histopatologia hepática, parasitologia, isqueiros, Anisakidae, Gymnotus spp.

\section{INTRODUCTION}

The tuvira (Gymnotus spp.), also called "sarapó", swordfish, "carapó" and "ituí" belongs to the same electric fish family. Its occurrence in the Pantanal river basin is in lentic environments with

IUniversidade Estadual de Mato Grosso do Sul (UEMS), Dourados, MS, Brasil.

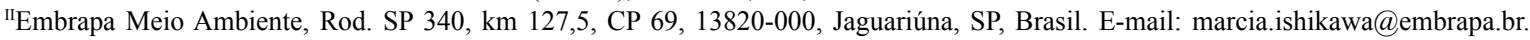
Corresponding author.

IIIUniversidade Federal da Grande Dourados (UFGD), Dourados, MS, Brasil.

IVUniversidade de São Paulo (USP), São Paulo, SP, Brasil.

VUniversidade Estadual de Maringá (UEM), Maringá, PR, Brasil. 
turbid water and aquatic vegetation rich in organic matter from flooding where it's their refuge and they can find food (ROTTA, 2004).

According to BARBIERI \& BARBIERI (1983ab, 1984) the average size of tuvira's first gonadal maturation can be set between $24,8 \mathrm{~cm}$ and $25,6 \mathrm{~cm}$, reaching maximum average length of $54,6 \mathrm{~cm}$. Stands out as live bait to be part of several species feed diet like the piscivorous species fish such as "dourado" Salminus brasiliensis and "surubins" Pseudoplatystoma sp. (PEREIRA \& RESENDE, 2006).

Nematodes of the Anisakidae family (RAILLET \& HENRY, 1912) and Acanthocheilidae (WULKER, 1929), have been recorded in several species of fishes (REGO, 1979; MORAVEC et al., 1997; ISAAC et al., 2004; PAVANELLI et al., 2004; MARTINS et al., 2005; 2009; GUIDELLI et al., 2006; BARROS et al., 2007; 2009; LACERDA et al., 2008; VICENTIN et al., 2011). Are characterized by being parasites that have heteroxenous cycle with its transmission involving fish, aquatic invertebrates as well as molluscs and crustaceans as intermediary hosts parathenic or definitive (ANDERSON, 2000).

The constant capture Gymnotideos reduced the number of specimens of this species in the natural environment, so the captive production can be an alternative for the local population, and reduce the capture of pressure on the natural environment (MORAES \& ESPINOZA, 2001). However, studies on the endoparasite fauna that affects the tuvira in confined environment, demonstrate that the parasites have limited its creation (ISHIKAWA et al., 2014).

Several studies have described the prevalence of parasites in this species (ISSAC et al., 2004; TAKEMOTO et al, 2009); however, there are no studies reporting the disease caused due to infection by these parasites. Due to the wide use of Gymnotus spp. as commercial bait fish farming becomes necessary to investigate the parasitic fauna of this species. It is important to know the hygiene and health conditions, and ambient water quality which is the creation of commercial baitfish farming, since the parasite may be related to cultivation environment.

The aim of this study was to evaluate the pathological changes in Gymnotus spp. liver caused by endohelminth.

\section{MATERIALS AND METHODS}

A total of 35 tuviras (Gymnotus spp.) were collected from different commercial bait fish farming

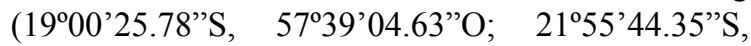

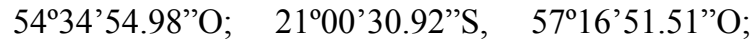

22\%08'06.04"S, 53³7'20.58”O) between April 2012 to October 2013, in the Pantanal basin in Mato Grosso do Sul, Brazil. Specimens were transported to Laboratory of Embrapa Agropecuária Oeste and euthanized by means of deep anesthesia with clove oil (150mg L $\mathrm{m}^{-1}$ ). The clove oil (WNF Ind. and Com. Ltda, São Paulo - SP) was obtained in natural food store and due to its oily nature, a stock solution was prepared in the proportion of $1 \mathrm{~g}$ of oil to $10 \mathrm{ml}$ absolute alcohol or alcohol $95^{\circ}\left(1 \mathrm{~g} 10 \mathrm{~mL}^{-1}\right)$ (VIDAL et al., 2006). The stock solution calculations were made to obtain the concentration of $150 \mathrm{mg} \mathrm{L}^{-1}$, according to the water volume from each tank where the fishes were euthanized.

In each specimen, besides the biometric data of weight and total length, it was also done research about endoparasites. The collected parasites were treated according to EIRAS et al., 2006 and identified based on MORAVEC (1998).

Fish liver samples were also collected infected with nematodes and processed in the Morphophysiology Laboratory of the Agricultural Sciences Faculty from the Federal University of Grande Dourados. Tissue pieces were fixed in $10 \%$ formalin, dehydrated in an ethanol gradual series clarified in xylol and saturated in paraffin. Histological sections of $7 \mu \mathrm{m}$ were stained with hematoxylin-eosin for tissue general analysis and also submitted to histochemical reaction from Perls Prussian Blue (Perls) for the evidence of the hemosiderosis degree $\left(\mathrm{Fe}^{+++}\right)$.

The hemosiderosis was evaluated in two ways, semi-quantitatively that punctuates from one to three, according to the incidence and severity deposit of $\mathrm{Fe}^{+++}$in each liver: a) Mean Value Calculation of Variation (MVV) according to the incidence (I- absence; II-punctual and III- extensive) adapted from SCHWAIGER et al., 1997; b) Calculation of Histopathological Variation Index (HVI), based on the lesion severity (I- does not affect the organ function; II- affects the organ function and III- irreversible), adapted from POLEKSIC \& MITROVIC-TUTUNDZIC (1994). Histological changes have been analyzed under a light microscope (in the increases $10 \mathrm{x} / 0,25$; $40 \mathrm{x} / 0,65$ and $100 \mathrm{x} / 1,25)$, linked to a camera in order to acquisition of digital images.

\section{RESULTS}

Specimens of Gymnotus spp. analyzed had a mean weight of $85,54 \pm 30,45 \mathrm{~g}$ and an average length of $29,80 \pm 3,91 \mathrm{~cm}$ (adults specimens). From the 35 
evaluated exemplars obtained a prevalence of $100 \%$ of nematodes parasitism. Some fishes presented more than one parasite species, being found six species of nematodes, Brevimulticaecum sp.; Eustrongylides sp; Contracaecum type I; Contracaecum type II; Contracaecum type III; a few specimens were identified only as larvae of Anisakidae, it was not possible to identify the gender (Table 1).

Macroscopic analysis of Gymnotus spp. liver showed red coloring brownish and friable consistency with the presence of several endocysts. Macroscopically, these cysts were whitish and were situated in the hepatic parenchyma near the organ surface, producing infection both in the central and peripheral regions, and in some samples, there was perforation of organ stroma, allowing externally viewing of the cyst.

Microscopic evaluation revealed cysts presence with one or up to five parasites, in $100 \%$ of livers analyzed. In some there were entire larvae, in others only intensely fibrosis amorphous materials (Figure 1). Several samples presented parasitic thrombus with vessel occlusion; however, it was not observed acute inflammatory process. It was also registered degenerated hepatocytes presence undergoing apoptosis at necrosis areas and hepatic parenchyma disorganization.

The hepatic tissues submitted to Perls histochemical reaction presented normal tissue interspersed with different $\mathrm{Fe}+++$ deposit degrees. The importance factor of hepatopathy revealed that $100 \%$ of the samples presented hemosiderosis severity in different stages for this metabolic change. The analysis results were as follows: Grade II, moderate intensity and with impared organ function, $10 \%$ and Grade III, severe hemosiderosis with irreversible changes $90 \%$.

In all livers it was also observed many macrophages and melanomacrophages centers
(MMCs) spread throughout the hepatic parenchyma forming small aggregates of heterogeneous materials, involving in an increasing manner all granulomatosis formation, which actively participated in the chronic parasitic and inflammatory reaction. Microscopically the MMCs have shown intensely blue colored (hemossiderin) resulting from the positive Pelrs reaction (Figure 2).

\section{DISCUSSION}

The encysted larvae of parasites are more pathogenic than those that lodge in the digestive tract (DICK \& CHOUDHURY, 1995). In general, the nematodes didn't cause specific response, few reports on fish mortality associated with the parasitic nematode (EIRAS et al., 2010). Among the species reported in this study no reports of mortality associated with Contraceacum sp in African freshwater fish (GRABDA, 1989).

The microscopic analysis results that denotes cysts and thrombus parasitic found on every livers are at different development stages, while some are fibrosis showing the process chronicity. However, it was not observed acute inflammatory process according to RODRIGUES et al. (2002) in Salminus maxillosus parasitized by Neocucullanus neocucullanus.

The lack of acute inflammatory process indicates that the parasite is not causing to the host a reaction with inflammatory cells, but the compression of the adjacent liver parenchyma, leading to a disorganization of the hepatocyte cords, small areas of necrosis and hemorrhage. Furthermore, the host presents a great amount of melanomacrophages centers and macrophages spread out throughout the parenchyma, as observed by DEZFULI et al. (2015), in the Perca fluviatilis liver parasitized by tapeworms, indicate that these individuals are in a chronic process

Table 1 - Parasites taxons reported in Gymnotus spp. collected from April 2012 to October 2013 in commercial bait fish farming in the Pantanal Mato Grosso do Sul basin.

\begin{tabular}{lllccc}
\hline Parasites & PF\EF & TP & Prevalence (\%) & Mean intensity & Plenty average \\
\hline Contraceacum type I & $24 \backslash 35$ & 304 & 68,6 & 8,7 & 12,7 \\
Contraceacum type II & $2 \backslash 35$ & 6 & 5,7 & 0,2 & 3 \\
Contraceacum type III & $2 \backslash 35$ & 3 & 5,7 & 0,1 & 1,5 \\
Eustrongylides sp. & $06 \backslash 35$ & 60 & 17,1 & 1,7 & 10 \\
Brevimulticaecum sp. & $09 \backslash 35$ & 99 & 25,7 & 2,8 & 11 \\
Anisakidae larvae & $04 \backslash 35$ & 15 & 11,4 & 0,4 & 3,8 \\
\hline
\end{tabular}

PF- parasitized fishes; EF- examined fishes; TP- total of parasites. 


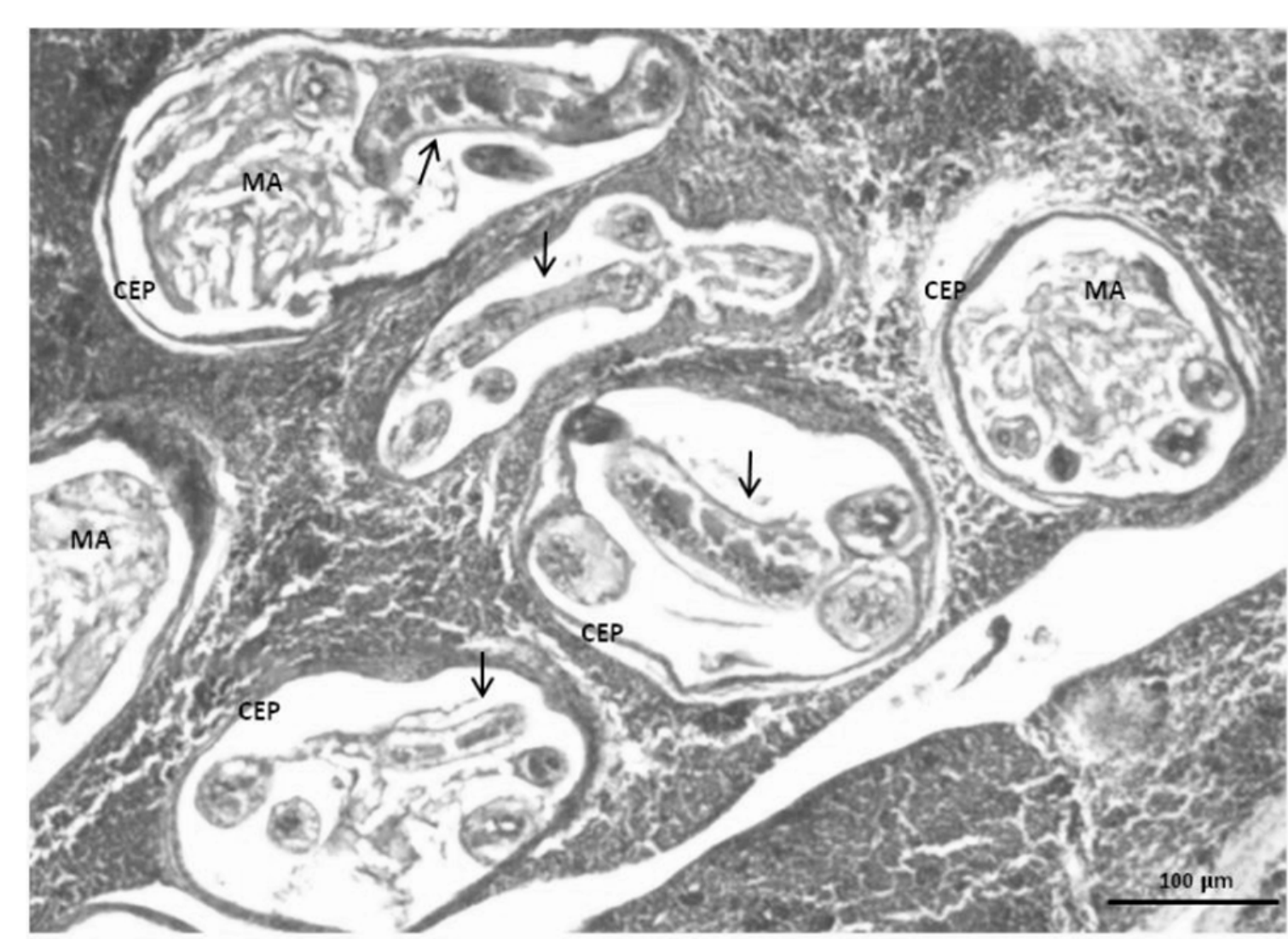

Figure 1 - Liver of Gymnotus spp. with capsule that involves the parasite (CEP), amorphous material (MA), encapsulated nematodes (arrows), 400X. HE.

and reacting immunologically to the parasite presence and or the presence of other stress agents.

Fibrosis lesions associated with small necrosis areas have been reported by SANTORO et al. (2013) in antarctic fishes and in this same study it was reported different degrees of chronic inflammation in liver tissue caused by larval forms of Contracaecum osculatum and Diphyllobothriidae, which corroborates the present study. This fact may explain the apparent tuviras resistance that even with intense parasitism by nematodes, with the presence of several endocistos in the liver, can maintain stable health.

In this way, it can be suggested that there is an equilibrium relation between tuvira and endoparasites, which may be committed in the presence of other stress agents such as management and inadequate water quality for the species, while capturing and commercialization, result in high mortality in commercial bait fish farming. This equilibrium relation can also be changed with the stress resulting from any type of pollution or even the climate variation naturally presented in the environment where tuviras are captured.

Hemosiderosis also registered in this study has provided a testimony to the condition of commercial bait fish farming in the current ecosystem conditions. The excessive accumulation of hemosiderin pigment is known as hemosiderosis, and reflects hemorrhage or hemolytic anemia (ROBERTS, 2001; WOLKE et al., 1985). In normal cell the Fe deposit may be reversible and does not cause functional change; however, according to the magnitude and persistence, can injure or destroy the cell.

The hemosiderosis of moderate to severe intensity was observed in $100 \%$ of livers analyzed and have as etiological agents: parasitic spoliation leading to an anemia and hemorrhage (ROBERTS, 2001; WOLKE et al., 1985), toxins, xenobiotics or iron intake arising from the aquatic environment (AYOADE \& ICULALA, 2007). Among other sources, distinct individual metabolic responses or stress might induce cellular changes by increasing 


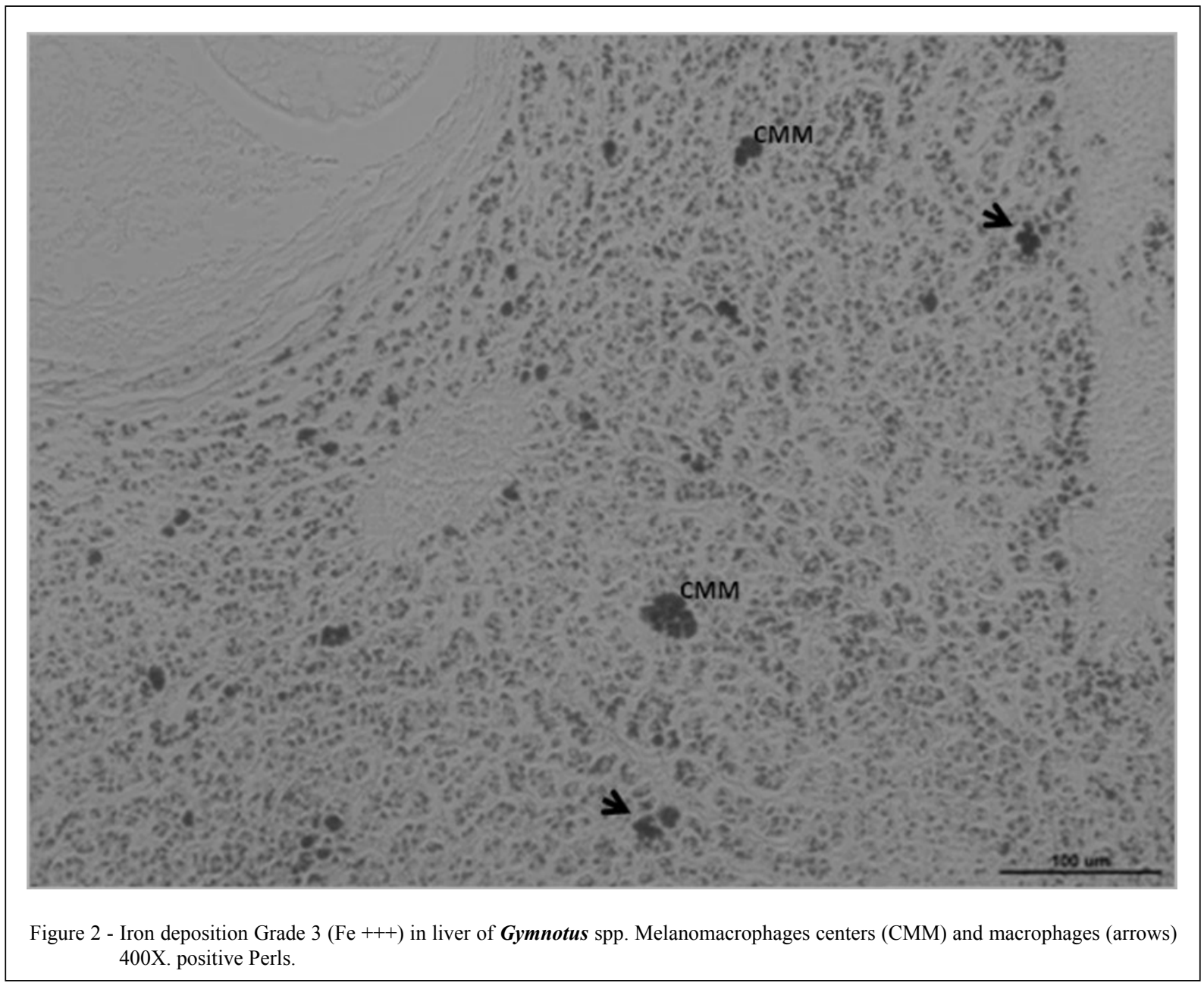

erythrocytes degradation and consequently the hemoglobin breaking, increasing the incidence metabolic Fe deposit. A moderate or severe degree of hemosiderosis observed in this study may indicate that the tuviras source environment is contaminated by endoparasites and/or other pollutant type.

The melanomacrophages center occurs in the fishes hepatic parenchyma. It forms large aggregates and increases in size after active phagocytosis of heterogeneous materials such as detritus, melanin (brown or black color), ceroid or hemosiderin and lipofuscin (natural yellowish color or blue) (AGIUS, 1980; MUNSHI \& DUTTA, 1996). Are utilized as bioindicators of water pollution (AYOADE \& ICULALA, 2007; BALAMURUGAN et al., 2012), as well as stressful factor indicators (HUR et al., 2006; ALAGAPPAN et al., 2009).

In the present study these results were observed probably due to the chronicity of parasitic infection. It is admitted the hypothesis that the parasites found in our study and histological changes caused by them may be responsible for the stimulation of the formation mechanisms of these centers. These results are in agreement with the results observed by AGIUS \& ROBERTS (2003) in teleost fishes where the presence of MMCs is due to the active phagocytosis period. These changes may be attributed even to age, sex and species of animals evaluated (DABROWSKA et al., 2012).

The studied tuviras come from capturing natural environment and is subsequently wrapped in commercial bait fish farming, in these environments the hygiene conditions are poor, a fact that own the development of diseases and disorders in animals.

\section{CONCLUSION}

The intense parasitic infection by nematodes, the histological findings as necrosis, disorganization of the hepatic parenchyma and 
pathogenic hemosiderosis, allied to the immunological response to the presence of melanomacrophages centers, suggests a chronic response and development of a balance relation between tuvira and intense parasitism by endohelminth identified in this study.

The data obtained in this study have provided information about the animals health and suggests that the quality of the aquatic environment from commercial bait fish farming and the environment where they were captured, may be compromised. As a suggestion for research development on this species, it is purposed the need for health monitoring studies, especially in the water quality of commercial bait fish farming and the environment where tuviras are captured.

\section{BIOETHICS AND BIOSSECURITY COMMITTEE APPROVAL}

This project was approved by the Ethics Committee for Animals Use of the Universidade Federal da Grande Dourados, protocol n. 005/2011.

\section{ACKNOWLEDGEMENTS}

This work was supported by the Fundação de Apoio ao Desenvolvimento do Ensino, Ciência e Tecnologia do Estado de Mato Grosso do Sul (FUNDECT), as part of the project Parasitological Evaluation and Hematological Characterization of Tuviras (Gymnotus sp.) Coming from commercial bait fish farming of Mato Grosso do Sul. Process: 23/200.202/2010.

\section{REFERENCES}

AGIUS, C. Phylogenetic development of melano-macrophage centres in fish. Journal of Zoology, v.191, p.11-31, 1980.

AGIUS, C.; ROBERTS, R.J. Melano-macrophage centres and their role in fish pathology. Journal of Fish Diseases, v.26, n.9, p.499-509, 2003. Available from: <http://onlinelibrary.wiley.com/ doi/10.1046/j.1365-2761.2003.00485.x/full>. Accessed: Apr. 25, 2015. doi: 10.1046/j.1365-2761.2003.00485.x.

ALAGAPPAN, K.M. et al. Histopathological alterations in estuarine catfish (Arius maculatus; Thunberg, 1792) due to Aeronomas hydrophila infection. World Journal of Fish and Marine Sciences, v.1, n.3, p.185-189, 2009.

ANDERSON, R.C. Nematode parasites of vertebrates. Their development and transmission. 2.ed. London: CAB Publishing, 2000. p.672.

AYOADE, A.A. et al. Length weight relationship, condition factor and stomach contents of Hemichromis bimaculatus, Sarotherodon melanotheron and Chromidotilapia guentheri (Perciformes: Cichlidae) in Eleiyele Lake, Southwestern Nigeria. Journal of Tropical Biology, v.55, n.3-4, p.969-977, 2007.

BALAMURUGAN, S.A. et al. Melanomacrophage centers aggregation in $\boldsymbol{P}$. lineatus spleen as bio-indicator of environmental change. Asian Pacific Journal of Tropical Disease, v.2, n.2, p.635-638, 2012. Available from: <http://www.sciencedirect. com/science/article/pii/S2222180812602357>. Accessed: Apr. 25, 2015. doi: 10.1016/S2222-1808(12)60235-7"10.1016/S2222$1808(12) 60235-7$.

BARBIERI, G.; BARBIERI, C.B. Growth and sexual maturation size of Gymnotus carapo (Linneus, 1758) in the Lobo reservoir (state of São Paulo, Brasil) (Pisces, Gymnotidae). Revista Hidrobiologia Tropical, v.16, n.2, p.195-201, 1983a

BARBIERI, G.; BARBIERI, C.B. Dinâmica da reprodução de Gymnotus carapo na represa do Lobo, estado de São Paulo. Influência de fatores abióticos (Pisces, Gymnotidae). Tropical Ecology, v.24, n.2, p.244-259, 1983 b.

BARBIERI, G.; BARBIERI. C.B. Crescimento de Gymnotus carapo Linnaeus, 1758 na represa do Lobo, estado de São Paulo, pelo método da distribuição da freqüência de comprimento (Pisces, Gymnotidae). Revista Brasileira de Biologia, v.44, n.3, p.239-246, 1984.

BARROS, L.A. etal. Larvas de nematóides de importância zoonótica encontradas em traíras (Hoplias malabaricus, Bloch, 1794) no município de Santo Antonio do Leverger, MT. Arquivo Brasileiro Medicina Veterinária Zootecnia, v.59, n.2, p.533-535, 2007. Available from: $<$ http://www.scielo.br/scielo.php?script $=$ sci artte xt\&pid=S0102-09352007000200042>. Accessed: Apr. 25, 2015. doi: 10.1590/S0102-09352007000200042.

BARROS, L.A. et al. Análise do parasitismo por Contracaecum sp. e Eustrongylides sp. em cacharas, Pseudoplatystoma fasciatum (Linnaeus, 1766) (Pisces: Pimelodidae) provenientes do rio Cuiabá, Mato Grosso, Brasil. Revista Brasileira Ciência Veterinária v.16, n.2, p.58-61, 2009.

DABROWSKA, H. et al. Histopathological, histomorphometrical, and immunohistochemical Biomarkers in flounder (Platichthys flesus) from the southern Baltic Sea. Ecotoxicology and Environmental Safety, v.78, n.1, p.14-21, 2012. Available from: <http://www. sciencedirect.com/science/article/pii/S0147651311003678>. Accessed: Apr. 25, 2015. doi: 10.1016/j.ecoenv.2011.10.025.

DEZFULI, B.S. et al. Ultrastructural assessment of granulomas in the liver of perch (Perca fluviatilis) infected by tapeworm. Journal of Comparative Pathology, v.152, n.3, p.97-102, 2015. Available from: $<$ http://www.sciencedirect.com/science/article/pii/ S0021997514003867>. Accessed: Apr. 25, 2015. doi: 10.1016/j. jcpa.2014.11.007.

DICK, T.A.; CHOUDHURY, A. Filo nematoda. In: WOO, P.T.K. Fish diseases and disorders. New York: CABE Publishing, 1995. V.1, Protozoan and Metazoan Infections, p.415-444.

EIRAS, J.C. et al. Métodos de estudo e técnicas laboratoriais em parasitologia de peixes. 2.ed. Maringá: EDUEM, p.199, 2006.

EIRAS, J.C. et al. Diversidade dos parasitas de peixes de água doce do Brasil. Maringá: Clichetec, p. 333, 2010.

GUIDELLI, G. et al. Fauna parasitária de Leporinus lacustris e Leporinus friderici (Characiformes, Anostomidae) da planície de inundação do alto rio Paraná, Brasil. Acta Scientiarum Biological Sciences, v.28, n.3 p.281-290, 2006. Available from: $<$ http://periodicos.uem.br/ojs/index.php/ActaSciBiolSci/article/ viewArticle/228>. Accessed: Apr. 25, 2015. doi: 10.4025/ actascibiolsci.v28i3.228. 
GRABDA, J. Marine fish parasitology: an outline. Weinheim, Verlagsgesellschaft, p. 306, 1989.

HUR, J.W. et al. Effects of starvation on kidney melanomacrophage centre in olive flounder, Paralichthys olivaceus (Temminck and Schlegel). Aquaculture Resesearch, v.37, n.8, p.821-825, 2006. Available from: <http://onlinelibrary.wiley. com/doi/10.1111/j.13652109.2006.01498.x/abstract?deniedAcce ssCustomisedMessage $=\&$ userIsAuthenticated $=$ false"userIsAuthe nticated $=$ false $>$. Accessed: Apr. 25, 2015. doi: 10.1111/j.13652109.2006.01498.x.

ISAAC, A. et al. Composição e estrutura das infracomunidades endoparasitárias de Gymnotus spp. (Pisces: Gymnotidae) do rio Baía, Mato Grosso do Sul, Brasil. Acta Scientiarum, v.26, n.4, p.453-462, 2004. Available from: <http://www.periodicos.uem.br/ ojs/index.php/ActaSciBiolSci/article/view/1527>. Accessed: Apr 25, 2015. doi: 10.4025/actascibiolsci.v26i4.1527.

ISHIKAWA, M.M. et al. Recomendações para redução da mortalidade na estocagem de tuviras em isqueiros. Dourados: Embrapa Agropecuária Oeste, 2014. 5p. (Circular Técnica n.25)

LACERDA, A.C.F. et al. List of species: Digenea, Nematoda, Cestoda, and Acanthocephala, parasites in Potamotrygonidae (Chondrichthyes) from the upper Paraná River floodplain, states of Paraná and Mato Grosso do Sul, Brazil. Check List, v.4, n.2, p.115-122, 2008

MARTINS, M.L. et al. Larval Contracecum sp. (Nematoda: Anisakidae) in Hoplias malabaricus and Hoplerythrinus unitaeniatus (Osteichthyes: Erythrinidae) of economic importance in occidental marshlands of Maranhão, Brazil. Veterinary Parasitology, v.127, n.1, p.51-59, 2005. Available from: <http:// www.sciencedirect.com/science/article/pii/S0304401704004200>. Accessed: Apr. 25, 2015. doi: 2004.09.026.

MARTINS M.L. et al. Sazonality of Eustrongylides sp. (Nematoda Dioctophymatidae) larvae in fishes from Paraná river, south-western, Brazil. Boletim Instituto de Pesca, v.35, n.1, p.29-37, 2009.

MORAES, A.S.; ESPINOSA, L.W. Captura e a comercialização de iscas vivas em Corumbá-MS. Corumbá: Embrapa Pantanal, 2201. 37p. (Boletim de Pesquisa, n.21).

MORAVEC, F. Nematodes of freshwater fishes of the Neotropical Region. . Praha: Academia. p. 464, 1998.

MORAVEC, F. et al. Some nematode of freshwater fishes in Venezuela. Folia Parasitol (Praha), v.44, p.3-47, 1997.

MUNSHI, J.S.D.; DUTTA, H.M. (Ed.). Fish morphology: horizon of new research. USA: Science Publisheers, p.300, 1996.

PAVANELLI, G.C. et al. Helminth fauna of fishes: diversity and ecological aspects. In: THOMAZ, S.M. et al. (Eds.). The upper Paraná river and its floodplain: physical aspects, ecology and conservation. Netherlands: Backhuys Publishers, Leiden, p.309$329,2004$.

PEREIRA, R.A.C.; RESENDE, E.K. Alimentação de Gymnotus cf carapo (Pisces: Gymnotidae) e suas relações com a fauna associada às macrófitas aquáticas no Pantanal, Brasil.
Corumbá: Embrapa Pantanal, 2006. p.52. (Boletim de Pesquisa e Desenvolvimento n.68)

POLEKSIC, V.; MITROVIC-TUTUNDZIC, V. Fish gills as a monitor of sublethal and chronic effects of pollution. In: MÜLLER, R.; LLOYD, R. (Eds.). Sublethal and Chronic effects of pollutants on freshwater fish. Oxford: Fishing News Books, p.339-352, 1994.

REGO, A.A. Contribuição ao conhecimento dos helmintos de raias fluviais Paratrygonidae. Revista Brasileira de Biologia, v.39, n.4, p.879-890, 1979.

ROBERTS, R.J. Fish pathology. 3.ed. Philadelphia: Saunders, p. 472,2001

RODRIGUES, E. de L. et al. Alterações histopatológicas em fígado de dourado Salminus maxillosus Valenciennes Valenciennes, 1840 (Osteichthyes, Characidae) causadas por Neocucullanus neocucullanus Travassos, Artigas \& Pereira 1828 (Nematoda). Acta Scientiarum Biological Science, v.24, n.2, p.455-459, 2002. Available from: $<$ http://eduem.uem.br/ojs/index. php/ActaSciBiolSci/article/view/2320>. Accessed: Apr. 25, 2015. doi: 10.4025/actascibiolsci.v24i0.2320.

ROTTA, M.A. Aspectos biológicos e reprodutivos para a criação da Tuvira (Gymnotus ssp.) em cativeiro. Corumbá: Embrapa Pantanal, 2004. 30p. (Documentos n.74).

SANTORO, M. et al. Parasitic infection by larval helminths in Antarctic fishes: pathological changes and impact on the host body condition index. Diseases of Aquatic Organisms, v.105, n.1, p.139-148, 2013. Available from: <http://www.nwhc.usgs.gov/hfs/ Globals/Products/DAO_2013.pdf $>$. Acessed: Apr. 25, 2015. doi: 10.3354/dao02626.

SCHWAIGER J. et al. The use of histopatological indicators to evaluate contaminant-related stress in fish. Journal of Aquatic Ecossystem, Stress and Recovery, v.6, n.1, p.75-86, 1997.

TAKEMOTO R.M. et al. Diversity of parasites of fish from the Upper Paraná River floodplain, Brazil. Brazilian Journal of Biology, v.69, n.2, p.691-705, 2009. Available from: <http://www. scielo.br/scielo.php?script $=$ sci arttext\&pid $=\mathrm{S} 151969842009000$ 300023\&lng=en\&nrm=iso\&tlng $=$ en $>$. Accessed: Sept. 28, 2015. doi: 10.1590/S1519-69842009000300023.

VICENTIN, W. et al. Metazon do parasites of Serrasalmus marginatus (Characiformes: Serrasalminae) in the Negro River, Pantanal, Brazil. Revista Brasileira de Parasitologia Veterinária; v.20, n.1, p.61-63, 2011. Available from: <http:// www.scielo.br/scielo.php?pid=S1984-29612011000100012HYP ERLINK\&script $=$ sci_arttext"script $=$ sci_arttext $>$. Accessed: Apr. 25, 2015. doi: $10.15 \overline{9} 0 / \mathrm{S} 1984-29612011000100012$.

VIDAL, L.V.O. et al. Utilização do eugenol como anestésico para o manejo de juvenis de Pintado (Pseudoplatystoma corruscans). Acta Scientiarum Biological Sciences, v.28, n. 3, p.275-279, 2006.

WOLKE, R.E. et al. Preliminary evaluation of the use of macrophage aggregates (MA) as fish health monitors. Bulletin of Environmental Contamination and Toxicology, v.35, n.1,p.222-227, 1985. Available from: $<$ http://link.springer.com/art icle/10.1007\%2FBF01636502\#page-1>. Accessed: Apr. 28, 2015. 